\title{
STATUTES AND TORT DEFENCES
}

\author{
JAMES GOUDKAMP*
}

I. Introduction

A striking feature of the English law of tort is that it is mostly judge-made. The rules that constitute it are found predominantly in the law reports rather than in the statutes books. This is especially true of the definitional elements of torts. Consider, for example, the building blocks of the action in negligence: a duty of care, a breach of that duty, and non-remote damage caused by the breach of duty. The principles that govern these components of the action are located almost exclusively in the common law, not in Acts of Parliament. Although we live in the 'age of statutes', ${ }^{1}$ they have escaped legislative intervention essentially unscathed. Much the same can be said of the definitional elements of most other torts, including all of the varieties of trespass, private and public nuisance, the tort recognised in Rylands $v$ Fletcher, and all of the economic torts. ${ }^{2}$ Stephen Sugarman summed up the situation when he said, 'tort remains, of all the law school courses we offer, the queen of the common law subjects. ${ }^{3}$ Sugarman was talking about tort law in the United States. But his observation applies also to the English law of torts.

Whereas legislation has had relatively little impact on the definitional elements of most torts, the experience in relation to defences to liability in tort has been radically different. Defences have been heavily affected by statute. The goal of this chapter is to address the relationship between statutes and defences. The analysis begins with an overview of the history of statutory modification of defences in England. This synopsis demonstrates the profound effect that legislation has had on defences. Attention then shifts to the extensive statutory reforms of Australian tort law that occurred at the start of the twenty-first century. This examination confirms the tendency of elected lawmakers in common law jurisdictions to concentrate on defences when legislating in relation to the law of tort. Some reasons for this focus are offered. Finally, several challenges posed by the 'statutorification' ${ }^{4}$ of defences are briefly discussed.

It is necessary to begin with an important terminological point. The term 'defence' bears several meanings in the tort law context. ${ }^{5}$ Accordingly, it is important to clarify at the outset how it will be used for the purposes of this chapter. The word will be restricted to 'affirmative defences'. 'Affirmative defences' are rules that, when applicable, exempt the defendant from liability even though all of the elements of a tort are in place. They include absolute and qualified privilege, arrest, distress, honest comment, ${ }^{6}$ immunities, limitation bars, necessity, and self-defence. In relying on any of these answers to liability, the defendant does not dispute the claimant's allegations. Rather, he endeavours to circumvent their legal effect. Denials of one or more of the elements of a tort, such as the pleas of 'inevitable accident' and

I am most grateful to Jenny Steele and TT Arvind for their valuable comments on a draft of this chapter. I am also indebted to Esther Kuforiji for her research assistance.

1 G Calabresi, A Common Law for the Age of the Statutes (Cambridge MA, Harvard University Press, 1982).

2 Of course, there are several torts that owe their existence to legislation, such as that of harassment (see s 3 of the Protection from Harassment Act 1977). However, the fact remains that the definitional elements of most torts are governed, wholly or predominantly, by the common law.

3 SD Sugarman, 'Assumption of Risk' (1997) 31 Valparaiso University Law Review 833, 833 n 1.

4 The term is Calabresi's: above $\mathrm{n} 1$ at 1.

5 For fuller discussion see J Goudkamp, 'A Taxonomy of Tort Law Defences' in S Degeling, J Edelman and J Goudkamp (eds), Torts in Commercial Law (Sydney, Lawbook Co, 2011) 441-443.

6 In Joseph v Spiller [2010] UKSC 53, [2011] AC 852 at 888 [117], 890 [130], the Supreme Court indicated that the defence of fair comment would henceforward be known as 'honest comment'. 
'act of God' in the context of the tort of negligence, will not, accordingly, be counted as 'defences'. Although these pleas are routinely referred to as 'defences', they are not affirmative defences. Nor will 'defences' be taken to include rules that merely restrict the remedy to which a successful claimant is entitled. Examples of such rules are the apportionment provision in s 1 of the Law Reform (Contributory Negligence) Act 1945 and the doctrines of provocation and mitigation of damage. Although, like affirmative defences, these devices fall for consideration only after it has been established that all of the elements of a tort are in place, they merely cut back the extent of liability. They do not prevent it from arising. Accordingly, they are distinct from affirmative defences.

\section{Statutes and defences: a very short history}

The aim of this part of the chapter is to survey important aspects of the history of statutory alteration of defences. It is convenient to separate the changes into three categories:

(1) statutory abolition of common law defences;

(2) statutory modification of common law defences; and

(3) statutory creation of defences.

This division does not exhaust the ways in which statutes intersect with defences. There are several other respects in which statutes and defences inter-relate. ${ }^{7}$ For example, a common law defence might be developed analogically by reference to a statute, a statute might incorporate a common law defence without altering its scope, and a statute might affect the procedure by which a common law defence is governed. For present purposes, however, it is expedient to describe legislative intervention in the defence context according to the three identified categories. This is because they capture the central ways in which statutes have impacted upon defences.

\section{A. Statutory abolition of common law defences}

A litany of common law defences have been removed by the fall of the statutory axe. One of the most important defences that came to an end in this way was that of contributory negligence. ${ }^{8}$ This defence was available where the claimant failed to take reasonable care for his safety and that failure contributed to his damage. It was irrelevant that the claimant's fault was trivial relative to the defendant's. Contributory negligence of any degree was fatal to the claimant's cause of action. The injustice that this rule was liable to cause led the courts to invent various devices in an attempt to contain it, the best known of which was the 'last opportunity doctrine'. However, when applicable, these devices simply cast full responsibility for the claimant's loss onto the defendant and ignored the claimant's responsibility for it. In other words, they left the all-or-nothing approach intact and did not, therefore, address the underlying problem. The Gordian Knot was cut by the legislature when it enacted the Law Reform (Contributory Negligence) Act 1945. This Act abrogated the defence and installed the apportionment provision in its place. ${ }^{9}$ This change probably had a greater effect on the practical operation of tort law than any other in the twentieth century, statutory or judge-made. ${ }^{10}$

Chief Justice French examines eight connections between statutes and tort law generally in R French, 'Torts in Commercial Law: Promiscuous Entanglement or Blessed Union?' in S Degeling, J Edelman and J Goudkamp (eds), Torts in Commercial Law (Sydney, Lawbook Co, 2011) ch 2.

8 Jenny Steele traces the political process that led to the abolition of this defence in ch 7 of this book.

9 Section 1(1).

10 See Jenny Steele's analysis at p.XXX. 
Following the demise of the defence of contributory negligence, certain other previously potent defences were toppled in fairly rapid succession. After a long period of gestation, Parliament enacted the Crown Proceedings Act $1947 .{ }^{11}$ This Act substantially removed the Crown's immunity. Only traces of it remained, some of which were done away with by subsequent statutes. ${ }^{12}$ The next defence to fall was that of common employment. ${ }^{13}$ This defence had been available to an employer who was sued by his employee in respect of injuries suffered due to the negligence of a co-worker. Following its severe restriction by both legislation ${ }^{14}$ and judicial decision, ${ }^{15}$ it was finally extinguished by the Law Reform (Personal Injuries) Act 1948. ${ }^{16}$ The legislature then proceeded to eradicate a suite of immunities. For example, in 1961 the immunity of highway authorities for nonfeasance was removed. ${ }^{17}$ A year later, the inter-spousal immunity was too. ${ }^{18}$ The immunity of landlords ${ }^{19}$ was for practical purposes removed by the Defective Premises Act $1972 .{ }^{20}$

It is worth noting that the abolition of the foregoing defences played a major role in the rise of the action in negligence. All too often, commentators concerned with the ascendency of this tort focus exclusively on the relaxation of its definitional elements, such as that which occurred in relation to the duty of care generally in Donoghue $v$ Stevenson, ${ }^{21}$ and the courts' tendency to raise the standard of the reasonable person. ${ }^{22}$ These liberalising changes were of course significant. However, the removal of the defences that have just been discussed also played a central (and, arguably, more important) role in enlarging the circumstances in which compensation is recoverable in negligence.

\section{B. Statutory modification of common law defences}

Many common law defences have been modified by legislation, some significantly. Since tracing more than a small fraction of these changes would quickly exhaust the reader's patience, what follows here merely delineates a selection of the more noteworthy alterations. Arguably the most significant legislative amendment of a common law defence in practical terms relates to the doctrine of volenti non fit injuria. ${ }^{23}$ An important context in which this principle was relevant was that of motor vehicle accidents ${ }^{24}$ and, in particular, claims by passengers injured by the negligence of their intoxicated host. ${ }^{25}$ In 1972, Parliament legislated

11 The Crown Proceedings Act 1947 is addressed in detail by TT Arvind in ch 19 of this book.

12 See, e.g., Crown Proceedings (Armed Forces) Act 1987.

13 Its downfall is described in PH Winfield, 'The Abolition of the Doctrine of Common Employment' (1949) 10 Cambridge Law Journal 191.

14 Employers' Liability Act 1880.

15 Several significant decisions are discussed in Winfield, above n 13 at 192-193.

16 Section 1(1).

17 Highways (Miscellaneous Provisions) Act 1961, s 1(1). See now Highways Act 1980, ss 41, 58.

18 Law Reform (Husband and Wife) Act 1962, s 1(1). The basis for this Act is a Law Reform Committee report: see Law Reform Committee, Liability in Tort between Husband and Wife (9th Report, Cmnd 1268, 1961).

19 Cavalier v Pope [1906] AC 428 (HL).

20 Section 4. The Act was based on a report by the Law Commission: see Law Commission, The Civil Liability of Vendors and Lessors for Defective Premises (Law Com No 40, 1970).

21 [1932] AC 562 (HL).

22 This tendency is discussed in PS Atiyah, The Damages Lottery (Oxford, Hart Publishing, 1997) 32-38.

23 Whether this doctrine is a defence is unclear. A plea of volenti may merely be a denial of the existence of an element of the action in negligence: see below Part III.B.vi. However, the conventional view is that the doctrine is a defence, which is why it is discussed here.

24 See, e.g., Baker v James Brothers \& Sons Ltd [1921] 2 KB 674 (KBD); Buckpitt v Oates [1968] 1 All ER 1145 (Devon Assizes); Bennett v Tugwell [1971] 2 QB 267 (QBD); Birch $v$ Thomas [1972] 1 WLR 294 (CA).

25 See, e.g., Dann v Hamilton [1939] 1 KB 509 (KBD); McCaig v Langan 1964 SLT 121 (OH). 
to exclude it from personal injury actions arising out of road traffic accidents. ${ }^{26}$ Cases in which the claimant was injured by the negligence of a drunken driver from whom he had accepted a ride were henceforward dealt with solely by way of apportionment for contributory negligence. The principal reason for this adjustment to the ambit of the doctrine of volenti was a desire to increase the access of persons hurt in motor vehicle accidents to insurance funds. ${ }^{27}$

The defence of discipline in so far as it relates to children has been altered by a complex network of legislation enacted against the background of the European Convention on Human Rights. ${ }^{28}$ For instance, s 548 of the Education Act $1996^{29}$ puts corporal punishment in schools beyond the defence's reach. This provision departs from case law that permitted such punishment provided that it was not excessive or maliciously motivated. ${ }^{30}$ Also worth mentioning is s 58(3) of the Children Act 2004. This subsection states: 'Battery of a child causing actual bodily harm to the child cannot be justified in any civil proceedings on the ground that it constituted reasonable punishment.' ${ }^{31}$ This provision establishes that contrary authority $^{32}$ is no longer good law.

Another defence the scope of which has been changed by statute is that of judicial immunity. ${ }^{33}$ The common law rules governing this immunity were (and, to an extent, still are) sensitive to factors thought ought to be irrelevant. For instance, superior court judges were afforded a wider immunity than their counterparts in inferior courts. Whereas judges in superior courts were protected in respect of acts committed beyond jurisdiction so long as they acted in good faith, ${ }^{34}$ judges in inferior courts were strictly liable for acts taken outside their jurisdiction. ${ }^{35}$ This differential treatment was impossible to justify. ${ }^{36}$ Since all judges perform the same basic function, they should all receive the same protection from suit. ${ }^{37}$ This logic was recognised by ss 31 and 32 of the Courts Act 2003. These sections went some distance towards placing judicial officers in inferior courts on the same footing in relation to the immunity as their brethren sitting higher in the court hierarchy. It is unnecessary to delve into the details of these provisions for present purposes. It suffices to say that they made a notable tweak to the immunity. In so far as they ensure that the scope of the immunity does not depend on the type of commission that a judge holds, they are welcome developments.

Parliament has enacted countless restrictions on the defence of exclusion of liability by contract or notice. The primary motivation for the creation of these restrictions has usually

26 Road Traffic Act 1972, s 148(3). See now Road Traffic Act 1988, s 149(3).

27 See HC Hansard, 5 February 1971, vol 810, cols 2092, 2110.

28 The focus has been on art 3, which prohibits 'inhuman or degrading treatment or punishment.'

29 Originally s 47 of the Education (No 2) Act 1986, as amended by s 293 of the Education Act 1993.

$30 \quad R$ v Hopley (1860) 2 F \& F 202, 206, 175 ER 1024, 1026 (Assizes); Mansell v Griffin [1908] 1 KB 947 (CA); $R v$ Newport (Salop) Justices; Ex parte Wright [1929] 2 KB 416 (Div Ct).

31 By s 58(4), 'actual bodily harm' has the same meaning that it bears in s 47 of the Offences Against the Person Act 1861. This Act does not define 'actual bodily harm'. The courts have said that these words need no explanation (DPP v Smith [1961] AC 290 (HL) 334). See further D Ormerod, Smith \& Hogan: Criminal Law, 12th edn (Oxford, Oxford University Press, 2008) 606-608.

32 In Av United Kingdom (1999) 27 EHRR 611, the European Court of Human Rights considered an application by a child who suffered extensive bruising due to a beating administered by his step-father in order to chastise him. The step-father was acquitted by a jury on a charge of battery (apparently) on the basis of the defence of discipline. The European Court held that English law, in permitting the infliction of such harm, breached art 3 of the Convention.

33 For discussion see A Olowofoyeku, Suing Judges: A Study of Judicial Immunity (Oxford, Clarendon Press, 1993), especially ch 2.

34 Fray v Blackburn (1863) 3 B \& s 576, 122 ER 217 (QB).

35 The fons et origo of the rule is the Marshalsea Case (1613) 10 Co Rep 68b, 77 ER 1027.

36 It was lamented by Lord Denning MR in Sorros v Moore [1975] QB 118 (CA) 136.

37 This is not to endorse the immunity that judges enjoy. For compelling argument against the immunity in its present form see J Murphy, 'Rethinking Tortious Immunity for Judicial Acts' (forthcoming at the conference Obligations VI: Challenging Orthodoxy). 
been to protect consumers, who tend not to read contracts and often have terms dictated to them. ${ }^{38}$ The most important restriction is that found in the Unfair Contract Terms Act 1977. ${ }^{39}$ Pursuant to s 2(1) of that Act, a person cannot exclude or restrict his liability for negligence in respect of personal injury or death by a contract or notice. According to $s$ 2(2), exclusions or restrictions on liability other than for personal injury and death are valid only if they are 'reasonable'. ${ }^{40}$ These provisions apply only to 'business liability', which is defined as liability for breach of obligations arising in the course of a business or from the occupation of premises used for business purposes. ${ }^{41}$.

Finally, it is worth touching on a collection of statutory adjustments that have been made to several common law defences to liability arising in defamation. ${ }^{42}$ Alterations have been made to the defences of innocent dissemination, justification (or truth), and honest comment. The Defamation Act $1996^{43}$ placed the defence of innocent dissemination on a statutory footing and enlarged it. ${ }^{44}$ At common law, this defence was restricted to distributors of defamatory statements. ${ }^{45}$ The 1996 Act provides that the classes of persons who can benefit from it are not closed. Anyone other than 'authors', 'editors', and 'commercial publishers', to whom the defence is expressly denied, are potentially protected by it. The main goal of this change was to bring printers within its net. ${ }^{46}$

Two statutory changes have been made to the defence of justification. The first was wrought by s 5 of the Defamation Act $1952 .{ }^{47}$ The provision is convoluted. However, in essence, it provides that where multiple charges have been laid against the claimant, the defence of justification will not fail only because the truth of every charge is not established so long as the words not proved to be true do not materially damage the claimant's reputation. So, for example, if the defendant states that the claimant is a paedophile and dim-witted and only proves that the claimant is a paedophile, the defendant will be able to succeed on the defence of justification since the claimant's reputation will not have been materially damaged by the imputation that he is dim-witted. Section 5 reverses the common law rule that, where an impugned statement contains multiple charges, all of them must be shown to be true in order for the defence of justification to succeed. ${ }^{48}$ The Rehabilitation of Offenders Act 1974 made the other adjustment to the defence of justification. This Act aims to promote the

38 A careful discussion of the reasons for legislative intervention in this regard is given in SA Smith, Atiyah's Introduction to the Law of Contract, 6th edn (Oxford, Clarendon Press, 2006) 326-330.

39 See also the Unfair Terms in Consumer Contracts Regulations 1999, SI 1993/2083 which implements the European Union Council Directive 93/13/EEC on Unfair Terms in Consumer Contracts [1993] OJL 095. Other statutory restrictions on contracting out of liability include the Law Reform (Personal Injuries) Act 1948, s 1(3); Public Passenger Vehicles Act 1981, s 29; Companies Act 2006, s 532.

40 The test of 'reasonableness' is dealt with, in fairly vague terms, by s 11 . It is considered in Smith v Eric S Bush [1990] 1 AC 831 (HL), especially at 858-859; Bank of Scotland v Fuller Peiser 2002 SCLR $255(\mathrm{OH})$.

41 Section 1(3). See also s 14.

42 Changes to certain of the statutes discussed here are currently being contemplated: see Ministry of Justice, Draft Defamation Bill, CP3/11 (London, The Stationery Office, 2011). This consultation paper is accessible online at <http://www.justice.gov.uk/downloads/consultations/draft-defamation-bill-consultation.pdf $>$.

43 The foundation of this Act was a report by the Supreme Court Procedure Committee, Report on Practice and Procedure in Defamation (London, Lord Chancellor's Department, 1991). See also the Lord Chancellor's Department, Reforming Defamation Law and Procedure: Consultation on Draft Bill (London, HMSO, 1995). The changes that the Act made to the common law are discussed in very helpful terms in DW Vick and L Macpherson, ‘An Opportunity Lost: The United Kingdom’s Failed Reform of Defamation Law' (1996) 49 Federal Communications Law Journal 621.

44 Section 1.

45 Emmens v Pottle (1885) 16 QBD 354 (CA).

46 Lord Chancellor's Department, above n 43 at [2.1]-[2.6].

47 This Act is based upon the Porter Committee's Report: see Lord Porter, Report of the Committee on the Law of Defamation, Cmd 7536 (London, HMSO, 1948). In relation to s 5, see the discussion at 21 [79]-[82].

48 Helsham v Blackwood (1851) 11 CB 111, 138 ER 412 (CCP). 
rehabilitation of offenders by restricting the disclosure of spent convictions. Section 8 is relevant to defamation actions. It is enlivened where the defendant publishes a statement that imputes that the claimant committed an offence if the claimant was convicted of the offence concerned and the conviction is spent. Once s 8 is triggered, the defence of justification will be unavailable unless the statement in question was made without malice. At common law, the defence of justification knew no such restriction.

The only statutory change to the defence of honest comment is that made by s 6 of the Defamation Act $1952 .{ }^{49}$ One of the preconditions to the application of this defence is that the defendant's opinion be based on true (or privileged) facts. At common law, if the facts on which the defendant's opinion was based were untrue in some respect, however minor, the defence would fail. ${ }^{50}$ Section 6 mitigates the stringency of this rule. It provides that the defence of honest comment shall not fail only because the truth of every allegation of fact is not proved provided that the comment is honestly made having regard to the facts alleged that are proved to be true.

\section{Statutory creation of defences}

Legislation provides for innumerable defences to liability in tort. This discussion here is, consequently, confined to a selection of the more interesting of these defences. Consider, first, limitation bars. Limitation bars, which provide the defendant with a defence to liability where the claimant fails to commence litigation within a certain time of the cause of action accruing, ${ }^{51}$ are an invention of Parliament. ${ }^{52}$ They were unknown to the common law. They are governed by an intricate web of legislation. ${ }^{53}$ The goals of limitation bars are diverse and complex and have not, unfortunately, been analysed comprehensively. ${ }^{54}$ However, their major suggested functions include promoting the efficient administration of justice by preventing litigation from being conducted on the basis of stale evidence, shielding defendants from the unfairness of being pursued in respect of long-forgotten wrongs, and encouraging claimants who have been wronged to forgive and forget.

A statutory defence of considerable political significance is the immunity of trade unions. ${ }^{55}$ From the middle of the nineteenth century until the start of the twentieth century, the courts generally aggressively developed the economic torts. ${ }^{56}$ The result of the expansion of these actions was that most forms of industrial action became tortious. Parliament responded by enacting the Trade Disputes Act 1906. This Act insulated those striking from liability in the economic torts. ${ }^{57}$ The scope of the immunity was adjusted many times over the twentieth

49 See Porter, above n 47 at 21-23 [83]-[91].

50 P Milmo, WVH Rogers and R Parkes (eds), Gatley on Libel and Slander, 11th edn (London, Sweet \& Maxwell, 2010) 352-353 [12.18].

51 The default limitation period applicable to actions in tort is six years: Limitation Act 1980, s 2. For personal injury cases, the limitation period is three years: s11(4). A limitation period of one year applies to proceedings in defamation and malicious falsehood: s 4A.

52 The Law Commission dates the first limitation bars to the 1200s: Law Commission, Limitation of Actions, (Law Com CP No 151, 1998) 4 [1.6].

53 The most important statute is the Limitation Act 1980.

54 A short but respectable discussion of the theoretical aspects of limitation bars is Alberta Institute of Law Research and Reform, Limitations, Report for Discussion 4 (Edmonton, Alberta Institute of Law Research and Reform, 1986) 24-39.

55 The context is discussed in Lord Hoffmann, 'The Rise and Fall of the Economic Torts' in S Degeling, J Edelman and J Goudkamp (eds), Torts in Commercial Law (Sydney, Lawbook Co, 2011) ch 6. See also ch 5 in the current book by Bob Simpson.

56 Lumley v Gye (1853) 2 E \& B 216, 118 ER 749 (QB); Quinn v Leathem [1901] AC 495 (HL); South Wales Miners Federation v Glamorgan Coal Co Ltd [1905] AC 239 (HL); Taff Vale Railway Co v Amalgamated Society of Railway Servants [1901] AC 426 (HL).

57 The immunity is now found in the Trade Union and Labour Relations (Consolidation) Act 1992, s 219. 
century. The last significant changes to it were made by the Thatcher Government. ${ }^{58}$ Key modifications made by that Government included rendering the immunity conditional upon the taking of a secret ballot of union members before strike action and withholding it from secondary action against suppliers and consumers.

Many statutory defences have been created in the context of defamation. The earliest such defence is the absolute privilege of Members of Parliament in respect of things said in Parliament, which was brought into being by art 9 of the Bill of Rights $1689 .^{59}$ The purpose of this privilege is to ensure that the law of defamation does not stifle frank debates in Parliament. It was discovered relatively recently that the privilege can disadvantage as well as protect Members of Parliament. In 1995, Mr Neil Hamilton, a Conservative MP, sued the Guardian over allegations of corruption (specifically, that he had accepted money in return for asking questions in Parliament). ${ }^{60}$ The Guardian pleaded justification. The court held that the privilege, in addition to immunising Members of Parliament, prevented the courts from inquiring into the business of Parliament and, hence, from considering evidence relevant to the Guardian's defence of justification. Mr Hamilton's action was stayed as a result since it would have been unfairly prejudicial to the Guardian to permit the proceedings to go to trial in circumstances where it would be prevented from justifying that which it had printed. This ruling prompted Lord Hoffmann to move an amendment to the Bill that became the Defamation Act 1996 to permit Members of Parliament to waive the privilege. ${ }^{61}$ This amendment was endorsed and the clause concerned became s 13 of the 1996 Act.

Two defences were created by the Parliamentary Papers Act 1840. Section 1 of this Act prevents actions from being maintained in respect of the publication of a 'report, paper, votes, or proceedings' ordered to be published by Parliament or published under the authority of Parliament. Pursuant to s 4, a person who 'prints' a Parliamentary 'report, paper, votes, or proceedings' on his own initiative is also granted a defence if he acted in good faith. Following the advent of broadcasting technologies, the latter answer to liability was subsequently extended beyond printed reports. ${ }^{62}$ The purpose of these defences is to facilitate the business of Parliament and to promote public understanding of it.

In an attempt to encourage the settlement of defamation actions, Parliament, in the Libel Acts of 1843 and 1845, created a defence of apology to liability in respect of statements published in a 'public newspaper or other periodical publication'. This defence is available if the following conditions are satisfied:

(1) the impugned statement was not maliciously published or published with gross negligence;

(2) the defendant published an apology;

(3) the apology was published before litigation was commenced or as soon as was practicable thereafter; and

(4) the defendant paid money into court.

This defence is obsolete since it is less advantageous than making a 'Pt 36 Offer' under the Civil Procedure Rules $1998 .{ }^{63}$ By making such an offer, the defendant can obtain costs protection without paying money into court or publishing an apology.

\footnotetext{
58 The Thatcher Government enacted numerous relevant Acts. The process began with the Employment Act 1980.

59 Article 9 provides that 'the freedome of speech and debates or proceedings in Parlyament ought not to be impeached or questioned in any court or place out of Parlyament.'

60 The litigation is discussed in K Williams, "“Only Flattery is Safe”: Political Speech and the Defamation Act 1996’ (1997) 60 Modern Law Review 388.

61 HL Debates, 7 May 1996, vol 572 cols 24-53.

62 Defamation Act 1952, s 9.

63 SI 1998/3132.
} 
In 1888, legislation was enacted that conferred absolute privilege on fair, accurate, and contemporaneous newspaper reports of court proceedings and proceedings of certain other public bodies. ${ }^{64}$ This legislation was supplemented by ss 8-9 of the Defamation Act 1952 (these sections limited the defence to reports of proceedings before domestic courts while enlarging it to include reports in the broadcast media) and then replaced by s 14 of the Defamation Act 1996. Section 14 of the 1996 Act widened the privilege in certain ways. It extended it to reports of certain international courts, such as the European Court of Justice. ${ }^{65}$ It also removed the requirement that the report had to be published by a newspaper or broadcast by television or radio signals. Any report, regardless of how it is published, is now potentially protected. The aim of this defence is to keep judicial proceedings under the public's gaze. Keeping the courts in the public's eye is important for a range of reasons, ${ }^{66}$ the foremost of which is that it guards against incompetence and corruption.

Section 7 of the Defamation Act 1952 created a qualified privilege in respect of publications in 'newspapers'. This defence exists concurrently with the defence of qualified privilege at common law. Section 7 was replaced by s 15 of the Defamation Act $1996 .{ }^{67}$ Section 15 provides that statements enumerated in Part I of Schedule 1 of the 1996 Act enjoy qualified privilege if they are of 'public concern' and were published 'for the public benefit.' Such statements include fair and accurate reports or proceedings in public of a legislature or court anywhere in the world. Statements mentioned in Part II of Schedule 1 are also privileged unless the claimant asked the defendant to 'publish in a suitable manner a reasonable letter or statement by way of explanation or contradiction' and the defendant 'refused or neglected to do so'. Statements falling within Part II are, in effect, subject to qualified privilege unless the defendant refuses the claimant a right of reply. Statements detailed in Part II mainly comprise reports of public information issued by local authorities in the United Kingdom or by institutions of a member state of the European Union. Unlike $\mathrm{s} 7$ of the 1952 Act, s 15 of the 1996 Act potentially casts its protection over all publications, whether or not printed in a newspaper.

The Defamation Act 1952 also provided for a defence of 'offers to make amends' ${ }^{68}$ This defence is now found in ss 2-4 of the Defamation Act $1996 .{ }^{69}$ Like the defence of apology, ${ }^{70}$ it aims to facilitate the settlement of claims where the defendant is 'innocent' despite publishing a defamatory statement about the claimant. An 'offer to make amends' is made when the defendant offers to publish a suitable correction, to make a sufficient apology, and to pay compensation plus costs. Liability will not arise if the claimant accepts the offer. If the offer is rejected, the defendant will also enjoy a defence unless he knew, at the time of publishing the statement, that it was defamatory of the claimant and false. The defence is granted in this situation in order to prevent claimants from maintaining defamation actions for primarily vindictive reasons.

Finally, it is worth turning attention to statutory defences that apply specifically to the tort of trespass to the person. There are, broadly speaking, five defences or classes of defences.

64 Law of Libel Amendment Act 1888, ss 3-4.

65 Defamation Act 1996, s 14(3).

66 These reasons were explored at length by Bentham: see J Bentham, The Works of Jeremy Bentham, vol 4 (Edinburgh, William Tait, 1843) 316-317 (ch L).

67 Section 15 is based on recommendations made in the Supreme Court Procedure Committee, above n 43 at ch 12 .

68 Section 4.

69 The current version of the defence has its foundation in the Supreme Court Procedure Committee, above n 43 at ch 7. It is considered in Milne v Express Newspapers Ltd [2004] EWCA Civ 664, [2005] 1 All ER 1021 1026-1030 [17]-[26]; Warren v The Random House Group Ltd [2008] EWCA Civ 834, [2009] QB 600 630631 [13]-[15].

70 See above the text accompanying n 63 . 
Take, first, the defence of prior private prosecution created by ss $44-45$ of the Offences Against the Person Act 1861. It is enlivened where the claimant brings a private prosecution against the defendant for assault and battery. Irrespective of the outcome of the prosecution, the fact that the prosecution was brought will furnish the defendant with a defence to civil liability in respect of the conduct on which the prosecution was based. The apparent rationale for this obscure defence is that it would be wasteful and unjust to permit the claimant to pursue the defendant in the civil sphere in light of the prior prosecution. ${ }^{71}$

Secondly, there is the defence of 'prevention of crime'. This defence is found in s 3(1) of the Criminal Law Act 1967. This provision provides: 'A person may use such force as is reasonable in the circumstances in the prevention of crime, or in effecting or assisting in the lawful arrest of offenders or suspected offenders or of persons unlawfully at large.' Section 3(1) is aimed primarily at relieving persons who use force to avert or terminate the commission of an offence from criminal liability. But it also provides an escape route from civil liability, a fact that tort lawyers have often failed to notice. This defence does not replace any common law defences. It co-exists with judge-made answers to liability. ${ }^{72}$

Thirdly, there are the law and order defences afforded to constables. These defences are scattered across many statutes. The most important piece of legislation in this connection is the Police and Criminal Evidence Act 1984. This Act authorises constables (and sometimes private citizens) to use force, ${ }^{73}$ to trespass on land, ${ }^{74}$ and to convert property ${ }^{75}$ in certain circumstances. The details of these defences cannot be given here. ${ }^{76}$ For present purposes, it suffices to say that they modernise and add considerably to the ill-defined authority given to constables by the common law to arrest offenders and suspected offenders, to enter upon private property, and to seize chattels. These statutory defences do not exclude any common law defences, although they have largely rendered judge-made answers to liability obsolete in this context.

Fourthly, a series of statutes authorise acts that would otherwise be actionable in battery or false imprisonment in order to facilitate the provision of medical treatment. The treatment of mentally disordered patients is governed primarily by the Mental Health Act 1983. There is insufficient space available to discuss the details of this statute. It suffices to say that it authorises treatment according to a complex system that contains many procedural and substantive safeguards. ${ }^{77}$ The position in relation to patients who lack capacity but who are not mentally disordered is determined mainly by the Mental Capacity Act 2005. Again, an indepth account of this intricate Act is beyond the ambit of this chapter. ${ }^{78}$ However, it is worth noting that the overarching principle it establishes is that a patient who lacks capacity may be

71 The Law Commission recommended that this defence be abolished: Law Commission, Legislating the Criminal Code: Offences against the Person (Law Com No 218, 1993) 138 [12.2]. In Wong v Parkside Health NHS Trust [2001] EWCA Civ 1721, [2003] 3 All ER 932, 938 [16], Hale LJ described it as 'anomalous'.

72 See the argument in A Ashworth, 'Self-Defence and the Right to Life' (1975) 34 Cambridge Law Journal 272, 285.

73 Section 24 confers on constables a power of arrest without a warrant. Section 24A grants private citizens a power of arrest. See also s 117, which permits constables to use reasonable force in the exercise of any of their powers under the Act.

74 See Pt II.

75 Sections 19-22. See also the additional seizure powers created by the Criminal Justice and Police Act 2001, Pt 2.

76 The defences are discussed at length in A Dugdale and M Jones, Clerk \& Lindsell on Torts, 20th edn (London, Sweet \& Maxwell, 2010) chs 15, 19.

77 Protection from civil liability is afforded by s 139.

78 It is discussed in Dugdale and Jones, above n 76 at ch 15. 
treated if the person providing treatment reasonably believes it to be in the patient's best interests. $^{79}$

The fifth defence is one that can loosely be described as one of illegality. Although an illegality defence is recognised by the common law, Parliament thought it necessary to create a statutory counterpart to it in the Criminal Justice Act 2003. This defence, which is found in s $329,{ }^{80}$ has sometimes been overlooked by torts scholars, no doubt because it is concealed in an Act that is concerned mainly with the criminal law. It operates in tandem with its common law sibling. ${ }^{81}$ Broadly speaking, it applies when:

(1) the defendant committed a trespass against the claimant;

(2) the claimant was convicted of an imprisonable offence in respect of conduct committed at the time of the defendant's trespass;

(3) the force used by the defendant was not 'grossly disproportionate'; and

(4) the defendant committed the trespass only because he believed ${ }^{82}$ that it was necessary to prevent the claimant from committing an offence, to protect life or property, or to apprehend the claimant.

The primary motivation for the creation of this defence was the Tony Martin saga. Mr Martin, a farmer, shot two burglars when they broke into his house (which had been repeatedly burgled). One of the burglars was killed and the other seriously injured. Mr Martin was convicted of manslaughter. ${ }^{83}$ There was considerable public sympathy for Mr Martin. The tabloid media argued that he deserved praise rather than punishment. Support for Mr Martin swelled when the surviving burglar commenced legally aided proceedings for damages against him. ${ }^{84}$ The outcry prompted Parliament to enact s 329 . Section 329 probably adds relatively little, if anything, to the protection afforded to defendants by virtue of the common law defence of illegality. Suppose that it had been in force when Mr Martin shot the burglars. What effect would it have had? Since the surviving burglar was sentenced to three years' imprisonment for conspiracy to burgle, it probably would have prevented him from recovering damages against $\mathrm{Mr}$ Martin had he prosecuted his action to judgment. However, his action would probably have failed anyway for illegality at common law. ${ }^{85}$ Section 329 would not have been triggered had proceedings been brought on behalf of the deceased burglar's estate since (obviously) he was not convicted of any offence. In this respect, s 329 is narrower than the defence of illegality at common law, which can apply to an action for the benefit of the estate of the victim of a tort. ${ }^{86}$

79 Section 5

80 For further analysis of s 329 see Adorian v Commissioner of Police of the Metropolis [2009] EWCA Civ 18; [2009] 1 WLR 1859; [2009] 4 All ER 227; JR Spencer, 'Legislate in Haste, Repent at Leisure’ (2010) 69 Cambridge Law Journal 19.

81 Section 329(6).

82 The belief does not need to be reasonable: s 329(8)(b).

83 This conviction was entered on appeal in place of a conviction at trial for murder. The appeal is reported in $R$ v Martin [2003] QB 1 (CA).

84 Steven Morris, 'Burglar has Right to Sue Tony Martin, Judge Rules’ Guardian (London, 14 June 2003) 7; Clare Dyer, 'Burglar Shot by Farmer Wins Right to Legal Aid' Guardian (London, 6 July 2002) 9. This action was eventually abandoned: Stewart Tendler, 'Burglar to 'Drop Case' Against Tony Martin' Times (London, 28 July 2003) 6.

85 Cf Revill v Newbery [1996] QB 567 (CA). In Revill, two burglars attempted to break into a shed owned by the defendant. The defendant was sleeping in it at the time in order to protect belongings that he kept inside it. He was roused by the burglars' attempts to gain entry. In an attempt to scare them away, the defendant fired a shotgun through a hole in the door. The blast struck one of the burglars. The injured burglar sued the defendant in several causes of action. The defendant's defence of illegality failed.

86 Burns v Edman [1970] 2 QB 541 (QBD). 


\section{Summary and general observations}

This conspectus of the history of legislative intervention in the law concerning defences revealed that it has been extensively altered by Parliament. These alterations have dramatically affected the incidence of liability in many contexts. For example, liability arising in the tort of negligence has been expanded enormously by the abolition or confinement of several common law defences. The elimination of the defences of contributory negligence and common employment and the restriction of the plea of volenti non fit injuria were landmarks in the evolution of this tort and, indeed, in tort law generally. These changes were arguably of far greater practical significance than any of the changes that have been made to the definitional elements of the action in negligence. Conversely, the circumstances in which the action in defamation lies have been significantly restricted by statute, principally by the creation of defences. Indeed, defamation has been the main breeding ground for statutory defences. Further statutory intervention in relation to defences to liability arising in this tort is imminent. The government recently published a draft bill that proposes significant changes to defamation defences. ${ }^{87}$ It seems to be committed to implementing these proposals.

Three general observations about the way in which the legislature has intervened in relation to defences are worth making. First, by and large, the changes that it has made, although numerous, have been relatively narrow. Sweeping changes, covering multiple torts, or many contextual settings, are less common. For example, the legislature has not chosen to create a generalised defence of justification that would apply wherever a defendant acted reasonably in committing a tort. Instead, it provided for a host of justificatory defences that have limited spheres of application, such as prevention of crime, the law and order defences granted to constables, and the defences that facilitate the provision of medical treatment. This tendency is readily explicable: there will usually be less resistance to tweaks being made to the law of defences than to across-the-board changes, all other things being equal.

Secondly, to a large extent, statutory defences, when created, have supplemented rather than replaced common law defences. Consider, for example, the statutory defence of prevention of crime, which overlaps with several common law defences, including arrest, illegality, and self-defence. This trend is also easily explained. Usually, it seems, the creation of a statutory defence is a response to complaints by a pressure group that liability is too extensive in some respect. If a relevant common law defence is replaced instead of being left to operate in tandem with a statutory defence, the possibility arises that the circumstances in which liability arises might unwittingly be reduced in some respect. Such a situation would be embarrassing for lawmakers. They are aware that the safer option is to add to the number of defences. This ensures that the zone of liability will not be accidentally increased. An unfortunate consequence of this state of affairs, however, is that it has contributed to tort law becoming increasingly complex. In some contexts, such as defamation and trespass to the person, the pool of defences has become exceedingly large.

Thirdly, the pendulum has swung against immunities. As the foregoing analysis revealed, ${ }^{88}$ immunities are heavily over-represented among extinct defences. ${ }^{89}$ Relatively few linger on. This situation is a result of a growing awareness of the odious nature of immunities. They are

87 See Ministry of Justice, above n 42.

88 See Part II.A.

89 Prosser remarked that ' $[\mathrm{t}$ ] he description of immunities today is largely the description of abandonment of and limitations on the immunities erected in an earlier day' (WP Keeton, DB Dobbs, RE Keeton and DG Owen, Prosser and Keeton on Torts, 5th edn (St Paul MN, West Publishing Co, 1984) 1032). The Reporters of the Restatement (Second) of Torts wrote that 'the modern tendency has been to view immunities with a considerable degree of disapproval and to insist upon good reasons for their continued existence. They have been restricted within increasingly narrow limits, either by statute or by decision' (ch 45A, Introductory Note). 
objectionable for several reasons, but primarily because they depart from the rule of law and create the impression that the law is guilty of favouritism. Although the erosion of immunities commenced at the beginning of the twentieth century, their decline, or at least the present hostility towards them, may, to an extent, be a product of the enactment of the Human Rights Act $1998 .{ }^{90}$

\section{Twenty-first century tort law reform in Australia}

This part of the chapter considers the statutory reforms of tort law in Australia that occurred at the start of the twenty-first century. The motivation for turning attention to these developments is threefold. First, the changes were far-reaching. They were easily the most significant modifications to tort law ever made in that country (legislative or judicial), and rank among the most wide-ranging alterations affected in any common law jurisdiction. ${ }^{91}$ Secondly, the legislature and some law reform bodies in the United Kingdom have paid close attention to the Australian changes. For example, when the Compensation Bill 2006 was debated in Parliament, the Australian reforms were discussed at some length. Proposals were made to include in the Bill provisions based on the Australian statutes. ${ }^{92}$ (These proposals did not come to fruition.) Similarly, the Young Report, ${ }^{93}$ which is the latest response by the government to England's 'compensation culture', ${ }^{94}$ was apparently influenced by the Australian statutes. Although the Australian legislation was not mentioned in the Young Report, some of the language used in it bears a striking similarity to certain of the provisions in the Australian Acts. It is improbable, therefore, that its author was not cognisant of these statutes. The Australian reforms may yet provide a model for statutory changes to tort law in England. Thirdly, the Australian reforms were concerned to a large extent with tort law's defence regime.

In order to properly understand the Australian reforms, it is necessary to appreciate the political context in which they occurred. Accordingly, it is with this background that the analysis begins. Key changes that the reforms made to tort law's defence regime will then be described.

\section{A. Background: the insurance crisis and the Ipp Report}

One of the most significant events in Australia at the start of the twenty-first century was an 'insurance crisis'. Between 2001 and 2002, premiums for liability insurance skyrocketed. These hikes, which were particularly pronounced in relation to medical indemnity and public liability insurance, had a profound impact on many parts of Australian society. Insurance

90 For valuable discussion of the relevance of the Human Rights Act 1998 to defences see Nicholas J McBride and R Bagshaw, Tort Law, 3rd edn (Harlow, Pearson Longman, 2008) 525-530.

91 Although the prize in this regard must go to the New Zealand accident compensation scheme, which was ushered in by the Accident Compensation Act 1972 (NZ). The current legislation is the Accident Compensation Act 2001 (NZ).

92 See, e.g., HL Hansard, 20 Dec 2005, vol 676, cols GC258-271.

93 Lord Young, Common Sense, Common Safety (London, HM Government, 2010). It is available online: $<$ http://www.number10.gov.uk/wp-content/uploads/402906_CommonSense_acc.pdf $>$. Analyses of the Report are offered in Annette Morris, “Common Sense Common Safety”: the Compensation Culture Perspective' (2011) 27 Journal of Professional Negligence 82; James Goudkamp, 'The Young Report: An Australian Perspective on the Latest Response to Britain's “Compensation Culture”' (2012) 28 Journal of Professional Negligence (forthcoming).

94 The 'compensation culture' is analysed by Annette Morris in ch 15 of this book. See also R Lewis, A Morris and K Oliphant, 'Tort Personal Injury Claims Statistics: Is there a Compensation Culture in the United Kingdom?' (2006) 14 Torts Law Journal 158; A Morris, 'Spiralling or Stabilising? The Compensation Culture and Our Propensity to Claim Damages for Personal Injury’ (2007) 70 Modern Law Review 349. 
became unaffordable for many or simply unavailable. Consequently, numerous small businesses were wound up, ${ }^{95}$ charitable events were cancelled, children's playgrounds were cordoned off, ${ }^{96}$ and many medical practitioners retired prematurely or threatened to do so. ${ }^{97}$ Even ANZAC Day (a national day of remembrance) commemorations ${ }^{98}$ and Christmas carols $^{99}$ were jeopardised. Politicians quickly realised that something significant had to be done (and be seen to be done) to combat the crisis.

Tort law was widely identified as the (or the main) cause of the insurance hikes. ${ }^{100}$ Encouraged by the media, which enthusiastically condemned the tort system by parodying it and the judges who administered it, ${ }^{101}$ politicians resolved to radically restrict both the circumstances in which compensation is payable and the quantum of recovery. They commissioned a Panel to guide them in making these changes. The Panel was chaired by the Hon Justice David Ipp AO, then an acting justice of the Court of Appeal of the Supreme Court of New South Wales (an intermediate appellate court in Australia). Its other members were Professor Peter Cane, ${ }^{102}$ a medical practitioner, and the mayor of a local council. ${ }^{103}$ The Panel's terms of reference required it to assume that ' $[t]$ he award of damages for personal injury ha[d] become unaffordable and unsustainable as the principal source of compensation for those injured through the fault of another'. ${ }^{104}$ The Panel was also asked to proceed on the footing that it was 'desirable to examine a method for the reform of the common law with the objective of limiting liability and [sic] quantum of damages arising from personal injury and death. $^{105}$

The Panel published its Report, which became known as the 'Ipp Report', in September 2002. ${ }^{106}$ It made 61 recommendations covering a wide range of topics, including the definitional elements of the action in negligence, vicarious liability, the assessment of

95 'Businesses Under Pressure' Canberra Times (Canberra, 28 March 2002) 2; D Buttler and n Webber, 'State of Despair: Insurance Crisis Costs Jobs, Festivals, Fun’ Herald Sun (Melbourne, 27 June 2002) 1.

96 'Field of Broken Dreams: Liability Bowls out Cricket Ground' Daily Telegraph (Sydney, 12 August 2002 ) 9.

97 G Healy and S Stock, 'Insurance is Ruining Us, Warn Doctors’ The Australian (4 December 2000) 6.

98 L Morris, 'Liability Crisis has Light Horsemen Galloping for Cover' Sydney Morning Herald (Sydney, 30 August 2002) 6.

99 S Sofios, 'Insurance Crisis Kills Santa’ Daily Telegraph (Sydney, 29 August 2002) 19; Frank Walker, 'HIH Insurance Crisis Cancels Christmas’ Herald Sun (Melbourne, 9 December 2001) 18.

${ }^{100}$ It is unclear whether tort law was causally related to the insurance crisis. Legal practitioners generally argued that the premium spike was caused by other factors such as the collapse of two major insurers, HIH and United Medical Protection Ltd, instability in the global financial markets following the terrorist attacks against the United States on 11 September 2001, the rising cost of reinsurance, and the aggressive underpricing of risks due to an overly competitive domestic insurance market: see Australian Plaintiff Lawyers Association, Inquiry to Review of the Law of Negligence: APLA Legal and Policy Submission (2002) 18 $<$ http://revofneg.treasury.gov.au/content/subs/042Plaintiff.pdf>; Law Council of Australia, Submission by the Law Council of Australia to the Negligence Review Panel on the Review of the Law of Negligence (2002) 3-4 $<$ http://revofneg.treasury.gov.au/content/subs/033LCA3.pdf $>$.

101 Analyses of the warped picture that the Australian media painted of tort law are provided in K Burns, 'Distorting the Law: Politics, Media and the Litigation Crisis: An Australian Perspective' (2007) 15 Torts Law Journal 195 and D Howard-Wagner, 'Who are the Real 'Heroes' and 'Villains': The Print Media's Role in Constructing the 'Public Liability Crisis' as a 'Moral Panic Drama' (2006) 10 Newcastle Law Review 69.

102 Peter Cane wrote a valuable article about the Panel's role in the reform process: Peter Cane, 'Reforming Tort Law in Australia: A Personal Perspective’ (2003) 27 Melbourne University Law Review 649.

103 The composition of the Panel was controversial. The competence and impartiality of the lay members was vigorously contested by associations representing legal practitioners.

104 Ministerial Communiqué, Terms of Reference: Principles Based Review of the Law of Negligence by a Panel of Eminent Persons <http://revofneg.treasury.gov.au/content/termsofref.asp>.

105 Ibid.

106 Commonwealth of Australia, Review of the Law of Negligence: Final Report (2002). (<http://www.revofneg.treasury.gov.au/content/Report2/PDF/Law_Neg_Final.pdf $>$ ). 
damages, expert evidence, and costs. Several of the Panel's most important recommendations related to defences. They included the following:

(1) The immunity of highway authorities for non-feasance, which the High Court of Australia dissolved at the height of the insurance crisis ${ }^{107}$ (to the dismay of many politicians), should not be resurrected. ${ }^{108}$

(2) Neither not-for-profit community organisations nor Good Samaritans should be given a special defence. ${ }^{109}$

(3) Providers of recreational services should be immunised from liability in respect of injuries suffered by a voluntary participant in a recreational activity as a result of the materialisation of an obvious risk of the activity. ${ }^{110}$

(4) Findings of 100 per cent contributory negligence should be authorised. ${ }^{111}$ (The High Court had held that such findings were impermissible. ${ }^{112}$ )

(5) When the defendant pleads volenti non fit injuria in respect of the materialisation of an 'obvious risk' of injury, the claimant should be presumed to have had knowledge of the risk. Furthermore, the knowledge element of the volenti doctrine should be satisfied provided that the claimant was aware of the general 'type or kind of risk'. It should not be necessary for the claimant to know of 'its precise nature, extent or manner of occurrence. ${ }^{113}$

\section{B. The legislative reaction $\underline{114}$}

It is a notorious fact that reports recommending reform of the law are often left to gather dust on library shelves. ${ }^{115}$ This was not the case with respect to the Ipp Report. In some

107 Brodie v Singleton Shire Council [2001] HCA 29; (2001) 206 CLR 512.

${ }^{108}$ Ipp Report, 152 [10.5].

${ }^{109}$ Ipp Report, Recommendations 10, 16.

${ }^{110}$ Ipp Report, Recommendations 11-12.

${ }^{111}$ Ipp Report, Recommendation 31.

112 Wynbergen v Hoyts Corp Pty Ltd [1997] HCA 52, (1997) 72 ALJR 65. English authority on this point goes both ways. Cases in which it was held that findings of 100 per cent contributory negligence are impermissible include Pitts v Hunt [1991] 1 QB 24 (CA) 48; Anderson v Newham College of Further Education [2002] EWCA Civ 505, [2003] ICR 212; Buyukardicli v Hammerson UK Properties plc [2002] EWCA Civ 683, [7]. It is arguable that support for this position can also be found in two opaque passages in Reeves Commissioner of Police of the Metropolis [2000] 1 AC 360 (HL) 372, 387. Occasions on which it was said that it is permissible to find 100 per cent contributory negligence include Imperial Chemical Industries Ltd v Shatwell [1965] AC 656 (HL) 672; McMullen v National Coal Board [1982] ICR 148 (QBD); Jayes v IMI (Kynoch) Ltd [1985] ICR 155 (CA) 159; McEwan v Lothian Buses plc [2006] CSOH 56, 2006 SCLR 592, 600-601 [32]-[35].

113 Ipp Report, Recommendation 32.

114 Numerous articles discuss the legislation enacted in the wake of the Ipp Report. For a small sampling see DA Ipp, 'Negligence - Where Lies the Future?' (2003) 23 Australian Bar Review 158; JJ Spigelman, 'Negligence and Insurance Premiums: Recent Changes in Australia Law' (2003) 11 Torts Law Journal 291; JJ Spigelman, 'Tort Law Reform: An Overview' (2006) 14 Tort Law Review 5; B McDonald, 'Legislative Intervention in the Law of Negligence: The Common Law, Statutory Interpretation and Tort Reform in Australia' (2005) 27 Sydney Law Review 443; Barbara McDonald, 'The Impact of the Civil Liability Legislation on Fundamental Policies and Principles of the Common Law of Negligence' (2006) 14 Torts Law Journal 268; J Dietrich, 'Duty of Care under the Civil Liability Act' (2005) 13 Torts Law Journal 17.

115 In England, the Law Commission Act 2009, amending the Law Commission Act 1965, attempts to rectify this situation. The major change that it makes is that it requires the Lord Chancellor to report to Parliament annually on the extent to which the Law Commission's proposals for reform have been implemented: see Law Commission Act 1965, s 3A. See also the Protocol between the Lord Chancellor and the Law Commission agreed pursuant to s 3B(1): Law Commission, Protocol Between the Lord Chancellor (on Behalf of the Government) and the Law Commission, (Law Com No 321, 2010) 6 [18]-[22]. This Protocol relevantly requires the government to correspond with the Commission following the publication of a report regarding its implementation. 
jurisdictions, such as New South Wales and Queensland, many of its recommendations were swiftly enacted, essentially verbatim. ${ }^{116}$ The legislatures in some other jurisdictions, such as the Territories, were more discriminating and only implemented a handful of the Report's recommendations. What follows here is a brief discussion of the reforms in so far as they concern defences. This analysis is quite general owing to the fact that the statutes are, regrettably, far from uniform. ${ }^{117}$

It is necessary to say a few words about the scope of the reforming Acts. Broadly speaking, they apply to civil liability for harm. They are not limited to claims in negligence or to proceedings in tort. Nor are they confined to actions in respect of personal injury or death. Consequently, their ambits are potentially extremely wide. However, most of their provisions are inapplicable to proceedings that are governed by motor vehicle accident or workers' compensation legislation (such legislation exists in most Australia jurisdictions ${ }^{118}$ ). Nor, for the most part, do they extend to tobacco and dust disease claims or to actions in the intentional torts.

\section{i. Immunity of highway authorities}

The legislatures in all States and Territories other than the Northern Territory resurrected the immunity of highway authorities for non-feasance in modified form. ${ }^{119}$ The immunity is couched in wildly different terms across Australia. However, in general, it protects 'road authorities' from liability in respect of harm arising from a failure to carry out roadwork unless the authority had actual knowledge of the risk that materialised. ${ }^{120}$ This immunity is unjustified. No compelling reason has been identified for affording road authorities, out of all public authorities, with special treatment. Furthermore, the immunity, like its common law ancestor, appears to draw many morally barren distinctions. ${ }^{121}$ For instance, in some jurisdictions, such as Tasmania, the immunity extends to risks arising due to the state of a 'road' but not, apparently, to risks created by structures situated on a road. Why should it matter, however, whether the claimant was injured as a result of a defect in a road as opposed to a defective structure positioned on it?

\section{ii. Good Samaritans}

All State and Territory legislatures enacted provisions conferring immunity on Good Samaritans. ${ }^{122}$ Good Samaritans are generally defined as non-professional rescuers.

${ }^{116}$ Indeed, the governments in some jurisdictions did not wait for the Ipp Report to be published. Controversially, the New South Wales government began its reform process before the Ipp Panel had been convened.

117 The scale of the discrepancies is surveyed in D Butler, 'A Comparison of the Adoption of the Ipp Report Recommendations and Other Personal Injuries Liability Reforms’ (2005) 13 Torts Law Journal 201.

118 See, e.g., Motor Accidents Compensation Act 1999 (NSW); Workers Compensation Act 1987 (NSW).

119 Civil Liability Act 2002 (NSW), s 45; Civil Liability Act 2003 (Qld), s 37; Civil Liability Act 1936 (SA), s 42; Civil Liability Act 2002 (Tas), s 42; Road Management Act 2004 (Vic), s 102; Civil Liability Act 2002 (WA), s 5Z; Civil Law (Wrongs) Act 2002 (ACT), s 113.

120 Shockingly, in South Australia, it seems that the immunity arises even if the authority had actual knowledge of the risk concerned. Thus, a road authority in that jurisdiction would not be liable to motorists injured by the collapse of a bridge for which it is responsible even if it knew that the bridge was unsafe and it could have easily brought it into repair. In the Australian Capital Territory, the immunity will be lost not only if the authority had actual knowledge of the risk but also if it should have reasonably had knowledge of the risk.

121 Several distinctions drawn by the common law immunity are criticised in B McDonald, 'Immunities under Attack: The Tort Liability of Highway Authorities and their Immunity from Liability for Non-Feasance' (2000) 22 Sydney Law Review 411.

122 Civil Liability Act 2002 (NSW), Pt 8; Civil Liability Act 2003 (Qld), ss 25-27; Civil Liability Act 2003 (SA), s 74; Civil Liability Act 2002 (Tas), ss 35A-35C; Wrongs Act 1958 (Vic), s 31A-31C; Civil 
Across Australia, the immunity is subject to various exceptions. For instance, in New South Wales, Tasmania, Western Australia, and the Territories, it is forfeited if the Good Samaritan's ability to exercise reasonable care was significantly impaired by voluntarily consumed alcohol or drugs. In Queensland, South Australia, Western Australia, and the Northern Territory, the immunity obtains only if the Good Samaritan acts in good faith and is not reckless.

The relevant Parliamentary Hansard ${ }^{123}$ reveals that, in creating the Good Samaritan immunity, the legislatures believed that the common law gave little or no protection to Good Samaritans beyond that afforded to defendants generally. In forming this view, which was apparently based on myths about the tort system in the United States, ${ }^{124}$ the legislatures were badly mistaken. As all lawyers know, the common law is reluctant to impose liability on Good Samaritans so as not to discourage altruism. ${ }^{125}$ The social utility of their conduct is factored into the negligence calculus. ${ }^{126}$ Allowances are also made where they acted in the agony of the moment. ${ }^{127}$ These principles ensured that only those Good Samaritans who proceed with a gross lack of regard for the welfare of others risked incurring liability. Consequently, it is unsurprising that the Ipp Panel recommended against changing tort law in so far as Good Samaritans are concerned. ${ }^{128}$ It is regrettable that this advice was ignored. The change means that, in at least some jurisdictions, Good Samaritans who cause injury through an egregious lack of care may be able to escape from liability in negligence. It is by no means clear that this is a sensible position for the law to adopt.

\section{iii. $\quad$ Volunteers}

The 2001-2002 insurance crisis hit community organisations particularly hard. This situation led to 'volunteers' being granted immunity from liability in respect of acts committed in good faith in all States and Territories. ${ }^{129}$ 'Volunteers' are defined as persons performing unpaid

Liability Act 2002 (WA), ss 5AB-5AE; Civil Law (Wrongs) Act 2002 (ACT), s 5; Personal Injuries (Liabilities and Damages) Act 2003 (NT), s 8. In some jurisdictions, Good Samaritan provisions already existed: see, e.g., Law Reform Act 1995 (Qld), Pt 5.

123 See, e.g., New South Wales Legislative Assembly, 30 October 2002, $6189 \mathrm{ff}$.

124 Some time ago, all jurisdictions in the United States enacted Good Samaritan statutes. These statutes restrict the liability of many types of rescuers, particularly medical professionals. Even before these statutes were enacted, it was almost unheard of for actions to be brought against Good Samaritans. The relevant statutes and common law are discussed in DB Dobbs, PT Hayden and EM Bublick, The Law of Torts, vol 2, 2nd edn (St Paul MN, West, 2011) 240-242.

125 This is not the only way in which the law has been fashioned so that it does not discourage rescue. For example, to increase the prospects of injured rescuers succeeding in proceedings as against those who created the need for rescue, the courts are loath to find rescuers guilty of contributory negligence or to hold that the rescue constitutes an intervening act. They generally refuse to find that rescuers voluntarily assume a risk of injury.

126 Watt $v$ Hertfordshire County Council [1954] 1 WLR 835 (CA) 838, [1954] 2 All ER 368, 371 ('The saving of life or limb justifies taking considerable risk' per Denning LJ).

127 Leishman v Thomas (1958) 75 WN (NSW) 173; Baker v TE Hopkins \& Son Ltd [1959] 1 WLR 966 (CA), [1959] 3 All ER 225.

128 See above $n 109$.

129 Civil Liability Act 2002 (NSW), s 61; Civil Liability Act 2003 (Qld), s 39; Volunteers Protection Act 2001 (SA), s 4; Civil Liability Act 2002 (Tas); s 47; Wrongs Act 1958 (Vic), s 37; Volunteers and Food and Other Donors (Protection from Liability) Act 2002 (WA), s 6; Civil Law (Wrongs) Act 2002 (ACT), s 8; Personal Injuries (Liabilities and Damages) Act 2003 (NT), s 7. See generally M McGregor-Lowndes and L Nguyen, 'Volunteers and the New Tort Law Reform' (2005) 13 Torts Law Journal 1. In all States and Territories, 'food donors' are also granted immunity: Civil Liability Act 2002 (NSW), s 58C; Civil Liability Act 2003 (Qld), s 38A; Civil Liability Act 1936 (SA), s 74A; Civil Liability Act 2002 (Tas), s 35F; Wrongs Act 1958 (Vic), s 31F; Volunteers and Food and Other Donors (Protection from Liability) Act 
community work on behalf of incorporated community organisations. The problem with this immunity is much the same as that of Good Samaritans. ${ }^{130}$ At common law, the social utility of volunteers' work meant that it was difficult for claimants to demonstrate that volunteers acted negligently, all other things being equal. Consequently, as the Ipp Panel noted, ${ }^{131}$ an adjustment to the liability of volunteers was unnecessary. The exposure of volunteers was already narrowly circumscribed. The only practical change that giving them immunity had was to insulate those volunteers who exhibit a glaring disregard for the interests of others from liability. It is far from obvious that such persons should be exempted from responsibility in tort.

\section{iv. $\quad$ Recreational service providers}

In New South Wales, Queensland, Tasmania, and Western Australia, recreational service providers have been given a new defence. ${ }^{132}$ This defence, which is based on recommendations made in the Ipp Report, ${ }^{133}$ applies only in the negligence context. It is triggered where the claimant is injured as a result of the materialisation of an 'obvious risk' of a 'dangerous recreational activity' in which he voluntarily engaged. An 'obvious risk' is a risk that would have been obvious to the reasonable person in the claimant's position. ${ }^{134} \mathrm{~A}$ 'recreational activity' is 'dangerous' if it entails 'a significant risk of physical harm.' 135 Whether a 'recreational activity' is 'dangerous' is determined objectively, so the fact that the claimant is unaware of a given risk is irrelevant for the purposes of this defence. Shooting kangaroos at night with the aid of a spotlight, ${ }^{136}$ diving into water from a wharf, ${ }^{137}$ and riding BMX bikes in a purpose-built skate park ${ }^{138}$ have been held to be 'dangerous recreational activities'. ${ }^{139}$ Touch football, ${ }^{140}$ spear fishing, ${ }^{141}$ dolphin watching from a boat, ${ }^{142}$ and weight lifting ${ }^{143}$ are not 'dangerous recreational activities'.

The reach of this defence is astounding. 'Dangerous recreational activities' probably include abseiling, boxing, bungee jumping, horse riding, jet skiing, rock climbing, rollerblading, skateboarding, scuba diving, sky diving, snow skiing, surfing, and water skiing. A claimant injured while participating in these activities by the materialisation of an obvious risk of the activity has no right to a remedy against his injurer. It is irrelevant that the injurer's fault is egregious. It is worth stressing that the breadth of this defence is far wider than that of

2002 (WA), s 8A; Civil Law (Wrongs) Act 2002 (ACT), s 11B; Personal Injuries (Liabilities and Damages) Act 2003 (NT), s 7A.

130 See above Part III.B.iii.

131 See above n 109.

132 Civil Liability Act 2002 (NSW), s 5L; Civil Liability Act 2003 (Qld), s 19; Civil Liability Act 2002 (Tas), s 20; Civil Liability Act 2002 (WA), s 5H.

133 See above n 110.

134 Authorities concerning the meaning of the phrase 'obvious risk' are discussed in C Sappideen and P Vines (eds), Fleming on the Law of Torts, 10th edn (Sydney, Lawbook Co, 2011) 343-344.

135 A significant risk has been held to be a risk that is somewhere between a trivial risk and a risk that is likely to materialise: Fallas v Mourlas [2006] NSWCA 32, (2006) 65 NSWLR 418, 422 [18], 432 [90]-[91].

136 Falvo v Australian Oztag Sports Association [2006] NSWCA 17, [2006] Aust Torts Rep $181-831$.

137 Jaber v Rockdale City Council [2008] NSWCA 98, [2008] Aust Torts Rep 981-952. Cf Hodder v Town of Port Hedland [2011] WADC 145, [295]-[296] (diving into a pool is not a 'dangerous recreational activity').

138 Vreman v Albury City Council [2011] NSWSC 39.

139 Professional horse racing was held to be a 'dangerous' but not a 'recreational' activity in Dodge v Snell [2011] TASSC 19, [239]-[289].

140 Falvo v Australian Oztag Sports Association [2006] NSWCA 17, [2006] Aust Torts Rep $981-831$.

141 Smith $v$ Perese [2006] NSWSC 288.

142 Lormine Pty Ltd v Xuereb [2006] NSWCA 200.

143 Drouet v Garbett [2011] WADC 100. 
the volenti principle. A claimant will only be volens to a risk of injury if he knew of it. ${ }^{144}$ In contrast, the defence under consideration here may apply even if the claimant was ignorant of the risk that materialised. Furthermore, the volenti defence is usually confined to risks that are inherent in an activity as opposed to risks that could have been reduced or eliminated by reasonable care. ${ }^{145}$ The immunity of recreational service providers is not similarly limited.

\section{v. 100 per cent contributory negligence}

The Ipp Panel, recall, recommended that, contrary to authority emanating from the High Court, findings of 100 per cent contributory negligence should be permitted. ${ }^{146}$ The Panel accepted that such findings would be 'very rare'. ${ }^{147}$ This begs the question why it bothered to make this recommendation. However, despite its limited practical significance, it was acted upon by the legislatures of all States and Territories except for those in South Australia, Western Australia, and the Northern Territory. ${ }^{148}$ The New South Wales provision is representative. It states: 'In determining the extent of a reduction in damages by reason of contributory negligence, a court may determine a reduction of $100 \%$ if the court thinks it just and equitable to do so, with the result that the claim for damages is defeated.' This provision restores the doctrine of contributory negligence to its former status as a defence in cases in which the claimant is wholly responsible for the damage about which he complains. ${ }^{149}$

Should courts be permitted to find contributory negligence in the order of 100 per cent? Let us consider the Ipp Panel's reasoning. The Panel began its analysis in this connection by examining the relationship between the doctrines of volenti non fit injuria and contributory negligence. (It did not explain its reasons for starting here, which is unfortunate as the relevant of this discussion to the proposition that courts should be allowed to find 100 per cent contributory negligence is not self-evident.) The Panel wrote: 'any conduct that ... amount[s] to voluntary assumption of risk ... also amount[s] to contributory negligence.' ${ }^{150}$ This is incorrect. While there is of course a substantial overlap between the doctrines of volenti non fit injuria and contributory negligence, it is quite possible for a claimant to be volens to a risk of injury without being guilty of contributory negligence. ${ }^{151}$ Voluntarily accepting some risks of injury might be reasonable. ${ }^{152}$ Consider, for instance, the decision in Murray $v$ Harringay Arena $L t d .{ }^{153}$ In this case, the claimant, a child, was injured while watching a ice-hockey game by an puck escaped from the rink. The Court of Appeal held that the doctrine of volenti non fit injuria applied. However, there was no suggestion that the claimant acted unreasonably with respect to his own safety.

\footnotetext{
144 Although see Part III.B.vi below regarding statutory reforms to the allocation of the onus of proof of knowledge.

145 Sappideen and Vines, above n 134 at 339.

146 See above $n 111$.

147 Ipp Report, 128 [8.25].

148 Civil Liability Act 2002 (NSW), s 5S: Civil Liability Act 2003 (Qld), s 24; Wrongs Act 1954 (Tas), s 4(1)(a); Wrongs Act 1958 (Vic), s 63; Civil Law (Wrongs) Act 2002 (ACT), s 47.

149 For examples of cases in which a finding of 100 per cent contributory negligence was made see Zilio $v$ Lane [2009] NSWDC 226; Adams v State of New South Wales [2008] NSWSC 1257, [131]-[133].

150 Ipp Report, 128 [8.23].

151 Except in South Australia, where legislation provides that the doctrine of volenti non fit injuria is limited to unreasonably running risks of injury: Civil Liability Act 1936 (SA), s 37(3).

152 As Fleming wrote: 'Obviously [the defence of volenti non fit injuria] bears much resemblance to contributory negligence. Frequently, the defences are raised in conjunction. But, like intersecting circles, the facts of a case may enliven one defence without the other. To assume a risk may in some circumstances be perfectly reasonable...' (Sappideen and Vines, above n 134 at 335 (footnote omitted)).

153 [1951] 2 KB 529 (CA).
} 
The Panel then wrote: ${ }^{154}$

'like the defence of contributory negligence, the defence of voluntary assumption of risk is only applicable once it has been decided that the defendant was negligent and that the harm suffered by the plaintiff was a result of that negligence. This shows that denying the plaintiff any damages need not be viewed as inconsistent with a finding that the defendant was negligent.'

With respect, this logic is flawed. The manner in which the volenti plea operates seems to have no bearing on the logic of finding a claimant guilty of 100 per cent contributory negligence. Certainly, any bearing that it has was left unexplained by the Panel. Let us focus, however, on the fact that the issue of contributory negligence only falls for consideration once it has been determined that the action in negligence is complete. The Panel evidently thought that this meant that concluding that a claimant is 100 per cent contributorily negligent is consistent with such a determination. This does not follow either. It merely means that a finding of contributory negligence of some degree is compatible with the definitional elements of the tort of negligence being established. It does not mean that notion of 100 per cent contributory negligence is consistent with the satisfaction of all of the elements of the tort.

The following sentence in the Ipp Report states: 'In other words, there may be cases in which the plaintiff's relative responsibility for the injuries suffered is so great that it seems fair to deny the plaintiff any damages at all. ${ }^{155}$ The most significant problem with this claim is that, even if it is sometimes fair to completely deny the claimant damages because his contribution to his loss is so great that it eclipses that of the defendant, it does not mean that this result should be achieved by entering a finding of 100 per cent contributory negligence. Why should this outcome not be realised instead, for instance, by holding that causation is not proved?

Finally, the Panel wrote: ${ }^{156}$

'It is important to remember that apportionment of damages is concerned with the issue of appropriate remedy, not with liability. It does not follow from a decision that the plaintiff should be denied any damages at all that the defendant was not at fault. Such a decision only means that as between the two parties at fault, the plaintiff should bear full legal responsibility for the harm suffered.'

No objection can be taken to this passage. However, it does nothing to support the proposition that findings of 100 per cent contributory negligence should be authorised. For example, it is of course true that a holding that the claimant is not entitled to damages does not mean that the defendant did not act carelessly. But it certainly does not follow from this that findings of 100 per cent contributory negligence should be allowed. Nor does it follow from a determination that the claimant should bear full responsibility for his damage that a finding of 100 per cent contributory negligence should be entered. Why should not the claimant's fault be taken into account in some other way?

It is submitted that the Panel's reasons for proposing that the courts should be permitted to find 100 per cent contributory negligence are unconvincing. Indeed, the Panel's analysis on this point at times veers into irrelevant issues and is infected with transparent non sequiturs. The fact of the matter is that the notion of 100 per cent contributory negligence is incoherent. To suggest that the claimant is guilty of 100 per cent contributory negligence is to say that he is wholly responsible for the damage about which he complains. However, if the claimant is wholly responsible for his damage, the defendant cannot have contributed to it. Without such a contribution, the definitional elements of the action in negligence will not be present. It follows that the question of contributory negligence cannot arise where the claimant's loss is exclusively his responsibility since the doctrine of contributory negligence only falls for

\footnotetext{
${ }^{154}$ Ipp Report, 128 [8.24].

155 Ipp Report, 128 [8.24].

156 Ipp Report, 128 [8.24].
} 
consideration if all of the components of the tort of negligence are present. Therefore, the concept of 100 per cent contributory negligence is a logical impossibility.

\section{vi. $\quad$ Volenti non fit injuria}

The doctrine of volenti non fit injuria ${ }^{157}$ applies only where the claimant knew of the risk that materialised. The common law places the burden of proving knowledge on the defendant. ${ }^{158}$ The Ipp Panel recommended that, where the risk of injury is 'obvious', it should be presumed that the claimant had knowledge of it. ${ }^{159}$ In other words, it proposed that the onus of proof in relation to the issue of knowledge be allocated to the claimant. This recommendation was acted upon in all States but not in the Territories. ${ }^{160}$ The Ipp Panel offered little by way of justification for suggesting this change to the law. It merely said: '[m]aking it easier to establish the defence ... would obviously promote the objective...' of limiting liability and the quantum of damages in the action in negligence. ${ }^{161}$ This is true but insufficient to justify this tweak to the rules governing the allocation of the onus of proof. It does not explain why the burden of proving the other elements of the volenti doctrine should not also be assigned to the claimant. Nor does it give us any reason to believe that calling on the claimant to disprove the knowledge element is among the better ways of realising the objective of confining liability. On the contrary, there are reasons for thinking that it is in fact a poor way of realising this aim. This is primarily due to considerations of coherence in the law concerning proof of defences. According to traditional learning, the volenti doctrine is a defence rather than a device that prevents one or more of the elements in the action in negligence from being satisfied. This conventional view was accepted by the Panel. ${ }^{162}$ If it is correct, ${ }^{163}$ the change to the allocation of the onus of proof in relation to the knowledge element is a departure from the principle that the defendant bears the onus of establishing defences. This rule is faithfully adhered to by tort law. There are very few exceptions to it. It is unfortunate that this consistency has been diminished. This is especially so given that it was for so little gain. The provision reversing the onus applies only if the risk in question was 'obvious'. However, if the risk in a given case is 'obvious', it will be rare for the knowledge element to be unsatisfied. A claimant who denies awareness of an obvious risk will usually be disbelieved. Accordingly, it is doubtful whether this change to the law is of any practical consequence. It follows that it was hardly worth sacrificing consistency in the rules governing proof of defences.

The Ipp Report also recommended that legislation provide that the element requirement of the volenti doctrine should be satisfied upon proof that the claimant knew, in general terms, of risk that materialised. ${ }^{164}$ The doctrine's application should not be conditional upon awareness of the fine details of the risk. This proposal was acted upon throughout Australia save in

157 Like in the United Kingdom (see above the text accompanying n 26), in New South Wales the doctrine does not apply in motor vehicle accident cases: Motor Accidents Compensation Act 1999 (NSW), s 140. In South Australia, the doctrine is inapplicable in certain cases in which the risk of injury resulted from the defendant's intoxication: Civil Liability Act 1936 (SA), s 47(6).

158 Insurance Commissioner v Joyce [1948] HCA 17, (1948) 77 CLR 39, 54.

159 See above $n 113$.

160 Civil Liability Act 2002 (NSW), s 5G(1); Civil Liability Act 2003 (Qld), s 14(1); Civil Liability Act 1936 (SA), s 37(1); Civil Liability Act 2002 (Tas), s 16(1); Wrongs Act 1958 (Vic), s 54(1); Civil Liability Act 2002 (WA), s 5N(1). In Victoria, this change does not apply in cases involving the provision of a 'professional service' or 'health service' or in claims in respect of the materialisation of 'risks associated with work done by one person for another' (Wrongs Act 1958 (Vic), s 54(3)).

161 Ipp Report, 129 [8.29].

162 Ipp Report, 128 [8.24].

163 For a powerful argument that it is mistaken see Sugarman, above n 3.

164 See above n 113. 
Victoria and the Territories. ${ }^{165}$ The New South Wales provision is typical. It provides: 'a person is aware of a risk if the person is aware of the type or kind of risk, even if the person is not aware of the precise nature, extent or manner of occurrence of the risk.' This change to the law is unobjectionable. It brings the plea of volenti into line with the principles that govern the doctrine of consent. Pursuant to this doctrine, a claimant consents to an interference with his interests if he agrees to the general class of interference concerned. For example, the consent of a patient to undergo a surgical procedure need not be specific to the precise instrument used to make the incision or the incision's exact size or location in order to prevent liability in battery from arising. It is enough that he agree to the general type of procedure. ${ }^{166}$

\section{vii. Intoxication}

All States and Territories enacted provisions dealing with intoxicated claimants. For the most part, the provisions in question are concerned with aspects of the tort law that do not relate to defences, such as the standard of care owed by the defendant to such claimants. The sole exception is s 50 of the Civil Liability Act 2002 (NSW), which creates a defence. Section 50 applies where the claimant's capacity to exercise reasonable care is 'impaired' by selfinduced intoxication, ${ }^{167}$ a very undemanding threshold (any degree of impairment would seem to be sufficient). When s 50 is triggered, the court must not award damages unless the injury 'is likely to have occurred' even if the claimant had not been intoxicated. ${ }^{168}$ Section 50 is one of the most unjust provisions in the tort reform statutes. It myopically focuses on whether the claimant's intoxication contributed to his loss. The defendant's responsibility is ignored. The potential for s 50 to operate harshly is easily illustrated. Suppose that the claimant, owing to his mild intoxication, does not notice an uncovered manhole in his path and falls into it. He is injured by the fall. The manhole is in a busy pedestrian area. It was left uncovered due to the negligence of a council employee who had been working on it. Section 50 would prevent the claimant from succeeding against the council. This is scarcely a just outcome. It is worth noting that $\mathrm{s} 50$ is one-sided in that it insensitive to intoxication by the defendant. So, for example, a claim by a slightly intoxicated claimant in respect of the negligence of a grossly intoxicated defendant might fail by virtue of s 50 .

\section{viii. Illegality ${ }^{169}$}

Potent illegality defences have been enacted in all States and Territories save for Victoria and Western Australia. ${ }^{170}$ These defences were created in response to a misguided belief that the

165 Civil Liability Act 2002 (NSW), s 5G(2); Civil Liability Act 2003 (Qld), s 14(2); Civil Liability Act 1936 (SA), s 37(2); Civil Liability Act 2002 (Tas), s 16(2); Civil Liability Act 2002 (WA), s 5N(2).

166 Chatterton $v$ Gerson [1981] QB 432 (QBD) 443.

167 Oddly, a claimant is regarded as intoxicated even if his intoxication is the result of taking medicine prescribed by a medical professional: s 48.

168 If it is not 'likely' that the injury would have occurred, damages may be awarded, but it is presumed that the claimant is guilty of contributory negligence: s 50(3). Unless the presumption is rebutted, damages must be reduced by at least 25 per cent: s 50(4).

169 I provided a review of the statutory illegality defences in James Goudkamp, 'A Revival of the Doctrine of Attainder? The Statutory Illegality Defences to Liability in Tort' (2007) 29 Sydney Law Review 445. See also James Goudkamp, 'Self-Defence and Illegality Under the Civil Liability Act 2002 (NSW)' (2010) 18 Torts Law Journal 61.

170 Civil Liability Act 2002 (NSW), ss 54-54A; Civil Liability Act 2003 (Qld), s 45; Civil Liability Act 1936 (SA), s 43; Civil Law (Wrongs) Act 2002 (ACT), s 94; Personal Injuries (Liabilities and Damages) Act 2003 (NT), s 10. No equivalent provision exists in Victoria or Western Australia. However, s 14G(2) of the Wrongs Act 1958 (Vic) provides: 'In determining whether the plaintiff has established a breach of the duty of care owed by the defendant, the court must consider ... whether the plaintiff was engaged in an illegal 
common law routinely enables persons injured while committing a criminal offence to profit from their wrongdoing. ${ }^{171}$ There are, unfortunately, substantial variations in the defences between the different jurisdictions. Generally speaking, however, they apply if the claimant was injured while committing a sufficiently serious offence and his offending contributed to his damage. There is no need for the claimant to be charged with or convicted of the offence concerned, let alone imprisoned. In some jurisdictions, the defences are subject to a safetyvalue discretion, which is exercisable where it would be harsh and unjust if the defence applied. ${ }^{172}$

The statutory illegality defences stand as a warning to lawmakers in other jurisdictions. They are among the most poorly drafted and unjust provisions in statutes that are hardly models of clarity and fairness. They serve no beneficial purpose. Contrary to what many politicians believe, they do not prevent wrongful profiting. This is because claimants almost never stand to make a net gain from damages awards in tort. Damages awarded in the tort context are usually only compensatory. It would be implausible to suggest that the defences deter offending. Persons contemplating whether to commit a criminal offence will usually only turn their minds to the criminal law, if they are concerned with the law at all. They will be unlikely to consider, or even be aware of, the statutory illegality defences. Finally, the defences cannot be justified on the ground that they punish where punishment is warranted. This is because they are pregnant with the potential to inflict punishment that is disproportionate to the gravity of the claimant's wrongdoing. The punishment that they mete out depends not on the claimant's blameworthiness but on the severity of his injuries. The greater the claimant's loss, the more that he will stand to lose more by liability being denied. The defences may also inflict double punishment since they are not excluded if the claimant is punished under the criminal law.

\section{ix. Self-defence $e^{173}$}

The New South Wales legislature, acting alone among the Australian legislatures, provided for a defence of self-defence in its tort reform legislation. ${ }^{174}$ This defence, which is found in s 52 of the Civil Liability Act 2002 (NSW), co-exists with the defence of self-defence at common law. ${ }^{175}$ It applies if the following circumstances are present:

activity.' This provision does not create a defence in the strict sense. Rather, the claimant's illegal act is merely a consideration to be borne in mind for the purposes of the negligence calculus.

171 The political focus was on a decision of the District Court of New South Wales (Fox v Peakhurst Inn Pty Ltd (unreported, District Court of New South Wales, McGuire DCJ, 29 August 2002)) to award nearly AUD\$50,000 (roughly £32,000) to an inebriated teenager who had been badly beaten by an occupier with a metal bar. This beating occurred when the teenager, having been denied entry into a night club because he was intoxicated and under-age, endeavoured to locate alternative access to the club via the occupier's premises. The teenager’s mother recovered AUD\$18,578 (approximately £12,000) in respect of a psychiatric injury that she suffered upon seeing her son in hospital. Predictably, the decision was condemned by the media (see, e.g., B Clifton, 'Outrage over Lout’s \$50,000’ Daily Telegraph (Sydney, 31 August 2002) 20). It was set aside by New South Wales Court of Appeal on procedural grounds: Fox v Peakhurst Inn Pty Ltd [2004] NSWCA 74. A newspaper reported that the teenager won on the re-trial: V Goldner, 'Drunk youth gets payout back’ Daily Telegraph (Sydney, 18 December 2004) 26.

172 Civil Liability Act 2002 (Qld), s 45(2); Civil Liability Act 1936 (SA), s 43(2); Civil Law (Wrongs) Act 2002 (ACT), s 94(2); Personal Injuries (Liabilities and Damages) Act 2003 (NT), s 10(2).

173 See generally Goudkamp (2010), above n 169.

174 Self-defence is controlled by statute in several other Australian jurisdictions. However, the relevant statutes in the other jurisdictions pre-date the tort reform legislation in issue in this chapter. Accordingly, they will not be discussed.

175 In n 171, above, the proceedings in Fox v Peakhurst Inn Pty Ltd were discussed. It was noted that this case provided the stimulus for the enactment of a statutory illegality in New South Wales. It seems that it also motivated the creation of the statutory defence of self-defence. 
(1) the defendant used defensive force against unlawful conduct or conduct that would have been unlawful but for the fact that the claimant was suffering from a mental illness;

(2) the defendant believed that using defensive force was necessary to defend himself or a third-party, to prevent or terminate a false imprisonment, to protect property or to prevent a criminal trespass; and

(3) the force used was reasonable in the circumstances perceived by the defendant. The defence in s 52 does not apply if the defendant intentionally or recklessly caused death only to protect property or prevent a trespass.

Section 52 is a seriously defective provision. The core problem with it is that it replicates the defence of self-defence in the criminal law of New South Wales. ${ }^{176}$ In the criminal law, the use of a subjective test in relation to the criterion of necessity may be appropriate. ${ }^{177}$ This is because it favours the defendant and, in the criminal law setting, the interests of the defendant must be given priority as a consequence of its retributive agenda. But a subjective test is inappropriate in the tort context ${ }^{178}$ since, in tort law, the interests of both parties should be given equal weight. An objective test would be more appropriate since it would do a better job of balancing the parties' interests.

Section 52 is supplemented by s 53 . Section 53 provides that, if s 52 would have prevented liability from arising had the defensive force been proportionate to the perceived threat posed by the claimant, the court must not award damages unless the case is exceptional and withholding damages would be harsh and unjust. If a court concludes that damages should be awarded under s 53, it cannot grant damages for 'non-economic loss'. ${ }^{179}$ Section 53 is also a badly misguided provision. Suppose that $C$ trespasses on D's property because of a mental illness from which he suffers. The presumption established by ss 52 and 53 is that D can inflict as much harm on $\mathrm{C}$ as he wishes (short of killing him). It matters not that $\mathrm{C}$ posed no real threat to D or to D's property interests. This rule, it is submitted, tips the scales much too far in favour of defendants.

\section{Summary and general observations}

The statutory reforms of tort law in Australia that have been described were an attempt to address an insurance crisis. They were severely restrictive of the circumstances in which liability arises and of the quantum of damages payable to successful claimants. Central to these reforms are several new defences. Generally speaking, these defences, like the statutory reforms generally, are hideous stains on Australian tort law. Some are premised on a defective understanding of the common law. Several of them impose arbitrary and unjust limits on liability. Most of them are appallingly drafted. It is hoped that they will not be used as models for the reform of the law elsewhere.

There are three further general points that are worth noting about the defences collectively. First, the defences were reactions to quite specific perceived problems. The exposure to liability in tort of Good Samaritans, volunteers, highway authorities, and providers of recreational services was seen as excessive. The solution in the eyes of the legislatures was to create defences for these defendants. Because these defences are limited to certain types of defendants, they diminished the generality of tort law. The liability of different types of

176 Crimes Act 1900 (NSW), Pt 11, Div 3.

177 Cf A Ashworth, Principles of Criminal Law, 6th edn (Oxford, Oxford University Press, 2009) 124-125.

178 The argument here is based on Ashley $v$ Chief Constable of Sussex Police [2008] UKHL 25, [2008] AC 962. In this case, a majority of the House of Lords opted for an objective test for self-defence.

179 Non-economic loss is defined in s 3 as pain or suffering, loss of amenities of life, loss of expectation of life, and disfigurement. 
defendants is now governed by different rules to a greater extent than was previously the case. This is not, in itself, problematic. In many fields, it is common to find laws directed against specific individuals. However, such piecemeal legislation tends to make the law more complex and renders it more difficult to identify themes and patterns in it.

Secondly, most of the new defences are immunities. In this respect, the Australian reforms stand in marked contrast with the English experience regarding defences. As noted earlier, in England, immunities have been steadily eroded. ${ }^{180}$ It was suggested that this trend may be due in part to the enactment of the Human Rights Act 1998. It is noteworthy in this regard that Australia (apparently uniquely among Western countries) lacks a national constitutional or legislative Bill of Rights. ${ }^{181}$

Thirdly, as has been the case with legislative intervention in the law concerning defences in England, ${ }^{182}$ the new Australian defences did not replace any common law defences. Judgemade defences were supplemented rather than substituted. The apparent reason for this situation was a concern not to accidentally diminish the protection afforded to defendants. Some Australian legislatures went to considerable lengths to preserve common law restrictions on liability. It is expressly stated in the reforming legislation in New South Wales and Tasmania that nothing in the statutes concerned is intended to lessen pre-existing limitations on liability. ${ }^{183}$ In the Tasmanian statute, as in the Queensland Act, it is also expressly stated that it not a code. ${ }^{184}$ Again, this provision seems to be designed to ensure the continuation of common law restrictions on liability.

\section{Explaining the legislative focus on defences}

The analysis so far has revealed that parliaments in England and Australia, when legislating with respect to tort law, have tended to concentrate on defences. The definitional elements of torts have been largely untouched by statute while the law on defences has been extensively modified. What is the reason for this focus? ${ }^{185}$ Two possible explanations suggest themselves. The first has to do with the political reality of the legislative process. It is usually significantly easier for a government to enact laws with tightly controlled ambits than laws that make farreaching changes. This is because proposals for extensive reforms will normally affect many more stakeholders. This greater interest will often create sufficient resistance to prevent them from coming to fruition. This seems to go some way towards explaining the disproportionate interest of the legislature in defences. Since statutory intervention in the defence context affects qualifications to general rules whereas changes to the definitional elements of torts alter the general rules themselves, legislative modification of defences is less likely to excite controversy than alterations of the definitional elements of torts all other things being equal.

A second explanation, which is closely related to the first, concerns the fact that legislation is not infrequently enacted in response to calls for reform by pressure groups. If the legislature is sympathetic to the complaints of a stakeholder about the state of the law, it will normally want to tailor its response to those complaints. In the tort setting, the easiest way to ensure a proportionate response will usually be to alter the law concerning defences. Specific stakeholders can be singled out for special treatment. Conversely, it may sometimes be more

\footnotetext{
180 See Part II.D.

181 See generally G Williams, A Charter of Rights for Australia, 3rd edn (Sydney, University of New South Wales Press, 2007). Statutory Bills of Rights exist in Victoria and in the Australian Capital Territory: Charter of Human Rights and Responsibilities Act 2006 (Vic); Human Rights Act 2004 (ACT).

182 See above Part II.D.

183 Civil Liability Act 2002 (NSW), s 3A(1); Civil Liability Act 2002 (Tas), 3A(2).

184 Civil Liability Act 2002 (Tas), s 3A(5); Civil Liability Act 2003 (Qld), s 7(5).

185 My concern here is to explain this focus rather than to rather than to assess its desirability. I will not speculate here on the latter issue.
} 
difficult to address complaints about the law by modifying the definitional elements of torts without the changes being more extensive than is necessary to alleviate a given stakeholder's anxieties about the law.

\section{Challenges for the future}

The ubiquity of statutory modification of defences presents several challenges for the future. This part of the chapter delineates a small selection of these difficulties. First, there is the problem of statutory provisions being overlooked. The vast number of statutory provisions relevant to defences has severely diminished the accessibility of tort law. This problem has been aggravated by the tendency of legislatures, particularly the English legislature, to scatter provisions concerning defences across countless acts. It has also been compounded by the fact that relevant provisions are not infrequently placed in acts that have little or nothing to do with tort law. Consider the statutory defences of illegality ${ }^{186}$ and prevention of crime ${ }^{187}$ in England. The provisions creating these defences are contained in statutes that are concerned predominantly with the criminal law. The titles of the acts in issue do not suggest that they have anything to do with tort law. It is little wonder that tort lawyers have often failed to notice that they exist.

The difficulty in identifying statutory provisions relevant to defences is now such that it is inevitable that material provisions will be overlooked by the courts and litigants. Where this happens, liability outcomes may not match the intentions of the legislature. Legislatures may also fail to notice provisions that they enacted with the result that duplicate provisions are created. This recently occurred in Queensland. As discussed above, ${ }^{188}$ the Queensland legislature enacted an illegality defence in 2003. However, it had already created such a defence in 1997. ${ }^{189}$ An inspection of the relevant Parliamentary Hansard, and the fact that the 1997 defence is significantly wider in certain respects than the 2003 defence, puts it beyond doubt that the Queensland lawmakers failed to notice the 1997 defence when they created the 2003 defence. Needless to say, the existence of duplicate provisions makes the law more complicated than it needs to be.

Secondly, the frenzy of statute-making concerning defences gives rise to difficult questions regarding the appropriate scope for judicial development of the law on defences. Arguably, the extensive intervention by the legislature in the defence setting means that the courts should be more reluctant to modify it than if it was largely a judge-made area. This is because the legislature has shown that it is attentive to the law on defences. The courts can be reasonably confident, therefore, that the legislature either regards it as up-to-date or that the legislature will modernise it if it perceives it to be defunct in some regard. On the other hand, it could be said that the fact that Parliament has left a given defence untouched does not mean that it is satisfied with it since there may be many other reasons for legislative inactivity (such as a lack of consensus as to how it should be reformed).

Thirdly, the growing influence of statutes in relation to defences is likely to present many difficult general issues of statutory interpretation. For example, to what extent should the courts remain committed to the presumption that the legislature does not intend to authorise tortious conduct? ${ }^{190}$ It seems difficult to uphold this principle considering the prodigious number of statutory defences that have been created. Similar remarks can be made about the

\footnotetext{
186 See above the text accompanying $n 80$.

187 See above the text accompanying $n 72$.

188 See above $\mathrm{n} 170$.

189 Criminal Law Amendment Act 1997 (Qld), s 4(2), amending s 6 of the Criminal Code Act 1899 (Qld).

190 For discussion of this presumption see Francis Bennion, Bennion on Statutory Interpretation: A Code, 5th edn (LexisNexis, London, 2008) 1074-1075.
} 
related presumption that the legislature does not intend to interfere with the liberty of persons. ${ }^{191}$ The explosion of statute-making in the defence context also presents other issues of statutory interpretation. Take, for instance, the situation where a common law concept is incorporated within a statutory defence. Is case law concerning the concept in question that predates its incorporation within the statutory defence relevant to the interpretation of the statutory text? Furthermore, does an incorporated concept become ossified at the moment that it is embedded in the statute or is development of it by the courts permissible? The latter question requires consideration of the extent to which statutes should be regarded as dynamic instruments.

Fourthly, the dominance of statutory law in the context of defences gives rise to the spectre of obsolescence. The classic treatment of the problem of anachronistic statutes is Guido Calabresi's book A Common Law for the Age of Statutes. ${ }^{192}$ Calabresi argued that the 'orgy of statute-making' in the twentieth century in the United States meant that America was being governed by laws that were outdated. He suggested that the courts had developed numerous ad hoc strategies to address anachronistic statutes. In these strategies, he saw the seeds of a new doctrine that would enable the courts to ensure that the law remains in phase with the modern world. This is not the place to engage with Calabresi's work or that of others who have addressed the same issue. The point to note here is that statutory obsolescence in the tort defence context is a cause for serious concern. Consider, for example, the defence of prior private prosecution, ${ }^{193}$ which was enacted almost 150 years ago. It was recently exposed by the Court of Appeal as a relic of an earlier time. ${ }^{194}$ Provisions creating several defences to liability in defamation are of a similar age. They have not been significantly revised and it is difficult to believe that they satisfy the needs of contemporary society.

Finally, there is the issue of the analogical use of statutes to develop the common law. In 1984, Patrick Atiyah queried whether the analogical use of statutes is permissible. He wrote: ${ }^{195}$

'[Is it possible] for the courts to take account of statute law... in the very development of the common law itself? Can the courts, for instance, use statutes as analogies for the purpose of developing the common law? Can they justify jettisoning obsolete cases, not because they have been actually reversed by some statutory provision, but because a statute suggests that they are based on outdated values? Could the courts legitimately draw some general principle from a limited statutory provision, and apply that principle as a matter of common law?'

In view of the proliferation of statutory defences, and the tendency of the legislature to supplement rather than to replace common law defences, the courts will probably need to consider these questions in the defence context in the near future. The constitutional arrangement of the legal system in which they are asked may be relevant in this connection. For instance, it is hard to see how the common law of Australia could be developed by analogy to statute unless at least several States and Territories had legislated in a similar way. ${ }^{196}$

\section{Conclusion}

Legislation has made a significant mark on tort defences. This chapter traced the history of statutory modification of defences in England. It also considered the more important defences

\footnotetext{
191 See Bennion, above n 190 at 836-840.

192 Above $n 1$.

193 Discussed above at the text accompanying $\mathrm{n} 71$.

194 See above $\mathrm{n} 71$.

195 PS Atiyah, ‘Common Law and Statute’ (1985) 48 Modern Law Review 1, 6.

196 Esso Australia Resources Ltd v Commissioner of Taxation [1999] HCA 67, (1999) 201 CLR 49 59-63 [18][28].
} 
created by the reforms of Australian tort law that occurred at the start of the twenty-first century. This analysis revealed the tendency of elected lawmakers to focus on defences as opposed to the definitional elements of torts when legislating with respect to tort law. It was suggested that this focus is explicable in view of the forces that spur the legislature into action. Finally, several challenges posed by the extensive legislative intervention in the defence setting were considered. These challenges include the problem of relevant provisions being overlooked in the sea of statutes, the role for judicial development of common law defences, the appropriateness of relying on principles of statutory interpretation established prior to the 'statutorification' of defences, the construction of common law concepts that have been incorporated into a statutory defence, the problem of statutory obsolescence, and the permissibility of analogical development of common law defences by reference to statutory developments. 